\title{
ASPEK HUKUM TATA NEGARA PADA PEMILIHAN KEPALA DAERAH SERENTAK DISAAT PANDEMI CORONA VIRUS DISEASE 2019 (COVID-19)
}

Oleh:

\author{
Kristian \\ Fakultas Hukum Universitas Palangka Raya
}

\begin{abstract}
Abstrak :
Penyebaran Corona Virus Disease 2019 (COVID-19) sebagai bencana nasional nonalam memerlukan kebijakan penanganan dan langkah-langkah luar biasa baik di tingkat pusat maupun daerah termasuk perlunya dilakukan penundaan tahapan pelaksanaan pemilihan gubernur dan wakil gubernur, bupati dan wakil bupati, serta walikota dan wakil walikota serentak tahun 2020. Pelaksanaan pemilihan kepala daerah memiliki tujuan agar pemilihan gubernur dan wakil gubernur, bupati dan wakil bupati, serta walikota dan wakil walikota tetap dapat berlangsung secara demokratis dan berkualitas serta untuk menjaga stabilitas politik dalam negeri, pada sisi lain kesehatan tetap terjaga dengan protokol kesehatan yang ketat dalam setiap tahapan pemilihan. Dampak dari wabah bencana non alam Pandemi Corona Virus Disease (Covid-19) yang terjadi sejak beberapa bulan yang lalu mengakibatkan Pemilihan Kepala Daerah (PILKADA) serentak yang sedianya dijadwalkan pada bulan September 2020 ditunda menjadi bulan Desember 2020 sesuai dengan terbitnya Peraturan Pemerintah Pengganti Undang-Undang (PERPPU) Nomor 2 Tahun 2020 yang secara teknis oleh KPU dibuat Peraturan KPU (PKPU) Nomor 6 Tahun 2020. Metode Penelitian menggunakan metode penulisan hukum normatif dan bertujuan memberikan penjelasan terkait perspektif hukum tata negara terhadap pelaksanaan pemilihan kepala daerah serentak di tengah wabah bencana nonalam Pandemi Corona Virus Disease (Covid-19). Hasil penelitian diharapkan bisa memberikan kontribusi bagi pengembangan keilmuan dalam bidang hukum.
\end{abstract}

Kata Kunci : Aspek Hukum Tata Negara, Pemilihan Kepala Daerah, Pandemi Corona Virus Disease (Covid-19)

\section{Abstract:}

The spread of Corona Virus Disease 2019 (COVID-19) as a non-natural national disaster requires handling policies and extraordinary steps both at the central and regional levels including the need to postpone the implementation stages of the election for governors and deputy governors, regents and deputy regents, as well as mayors and deputies Concurrent mayors in 2020. The implementation of regional head elections has the aim that the election for governors and deputy governors, regents and deputy regents, as well as mayors and deputy mayors can continue in a democratic and quality manner and to maintain domestic political stability, on the other hand health is maintained by strict health protocols at every stage of selection.The impact of the non-natural disaster pandemic Corona Virus Disease (Covid-19) which occurred several months ago resulted in the simultaneous Regional Head Election (PILKADA) which was originally scheduled for September 2020 to be postponed to December 2020 in accordance with the issuance of a Government Regulation in Lieu of Law (PERPPU) Number 2 of 2020 which is technically made by the KPU. KPU Regulation (PKPU) Number 6 of 2020.The research method uses the normative legal writing method and aims to provide an explanation regarding the constitutional law perspective on the 
implementation of simultaneous regional head elections in the midst of a non-natural disaster pandemic Corona Virus Disease (Covid-19). The research results are expected to contribute to scientific development in the field of law.

Keywords: Aspects of Constitutional Law, Regional Head Elections, Corona Pandemic Virus Disease (Covid-19)

\section{PENDAHULUAN}

Indonesia merupakan sebuah negara yang sangat besar baik dari jumlah penduduk maupun geografisnya. Kekayaan alam, suku dan ragam budaya yang melimpah membuat Indonesia menjadi sebuah negara yang perlu diatur dari berbagai sisi. Perlu diketahui bahwa Negara Kesatuan Republik Indonesia (NKRI) adalah negara hukum, hal ini tertuang dalam Undang-Undang Dasar Negara Republik Indonesia Tahun 1945 (UUDNRI 1945) Pasal 1 ayat 3 yang berbunyi "Negara Indonesia Adalah Negara Hukum". (Perubahan Ketiga UUD NRI 1945). Sejak diproklamirkannya kemerdekaan Indonesia pada tanggal 17 agustus tahun 1945, sampai saat ini Undang-Undang Dasar 1945 sudah beberapa kali mengalami perubahan. Pada awalnya bernama Undang-Undang Dasar 1945 (UUD 1945), selanjutnya Konstitusi Republik Indonesia Serikat (RIS) tahun 1949, lalu kemudian beralih kepada Undang-Undang Dasar Sementara (UUDS 1950), hingga kembali ke UUD 1945 pasca terbitnya Dekrit Presiden Tahun 1959, bahkan setelah gerakan reformasi yang terjadi pada tahun 1998, UUD 1945 telah mengalami empat kali perubahan (amandemen) dari perubahan pertama Tahun 1999 sampai Tahun 2002 pada perubahan keempat. Hal tersebut tidak terlepas dari pengaruh politik hukum yang berkembang pada saat itu.

Kekuasaan negara dalam sebuah negara bertumpu pada 3 (tiga) hal yaitu : kekuasaan legislatif, kekuasaan eksekutif dan kekuasaan yudikatif. Sistem hubungan, tata kerja dan koordinasi antara ketiga kekuasaan itu disebut sistem pemerintahan Negara. (Ahmad, 2012). Sistem pemerintahan berkenaan dengan mekanisme yang dilaksanakan oleh pemerintah dalam menjalankan fungsi, tugas dan wewenang. Demikian juga untuk sistem pemerintahan negara Indonesia mulai dari pemerintah pusat hingga pemerintah daerah, untuk pemerintah daerah termasuk mekanisme pemilihan kepala daerah secara langsung dan serentak sebagaimana diterapkan di Indonesia sejak pilkada serentak tahun 2015.

Pada konteks negara yang demokratis beberapa negara di dunia termasuk 
Indonesia seyogyanya melakukan periodesasi pemilihan pemimpin secara berkala dan berkelanjutan. Pemilihan pemimpin daerah hingga nasional dilakukan setiap 5 (lima) tahun sekali. Pemimpin daerah yang dimaksud yaitu yakni gubernur dan wakil gubernur, bupati dan wakil bupati, serta walikota dan wakil walikota. Pergantian pemimpin daerah sebagaimana dimaksud dilakukan melalui sebuah pemilihan umum kepala daerah yang dilakukan secara serentak dan demokratis. Pada tahun ini pemilihan kepala daerah rencananya dilakukan pada tanggal 9 desember 2020. Pemilihan kepala daerah dianggap sebuah hajatan besar bagi sebagian daerah yang melakukan pemilihan pemimpinnya disambut dengan penuh rasa dan suasana keprihatinan karena bencana nonalam pandemi Corona Virus Disease (Covid19). Pandemi Covid-19 merupakan bencana yang sangat berpengaruh bagi setiap sendi kehidupan di berbagai sektor seperti ekonomi, sosial, hukum, kesehatan dan lain sebagainya.

Upaya penanggulangan penyebaran Corona Virus Disease 2019 (COVID-19) sebagai bencana nasional perlu diambil kebijakan dan langkah-langkah luar biasa baik di tingkat pusat maupun daerah termasuk perlunya dilakukan penundaan tahapan pelaksanaan pemilihan gubernur dan wakil gubernur, bupati dan wakil bupati, serta walikota dan wakil walikota serentak tahun 2020 agar pemilihan gubernur dan wakil gubernur, bupati dan wakil bupati, serta walikota dan wakil walikota tetap dapat berlangsung secara demokratis dan berkualitas serta untuk menjaga stabilitas politik dalam negeri.

Demokrasi dapat diartikan sebagai kedaulatan rakyat atau rakyat yang berdaulat. Rakyat yang berwenang dan menentukan siapa yang akan menjadi wakil dan pemimpin mereka melalui sebuah pemilihan umum yang langsung umum bebas rahasia jujur dan adil (Luberjurdil). Pada awalnya jadwal pemilihan kepala daerah (pilkada) serentak sedianya dilaksanakan pada bulan September 2020 namun akhirnya ditunda pada tanggal 9 Desember 2020.

Hukum Tata Negara (HTN) menjamin roda demokrasi berjalan secara tetap dan periodik (berkelanjutan), pelaksanaan pilkada serentak merupakan suatu pengejawantahan dari sistem politik demokrasi yang dijamin oleh HTN sebagai salah satu aturan hukum dalam penyelenggaraan kehidupan bernegara. Oleh karena itu HTN sebagai aturan hukum seyogyanya memandang bahwa putaran pemilihan kepala daerah tidak bisa ditiadakan karena kondisi pandemi covid19 seperti saat ini namun hanya bisa 
ditunda penyelenggaraannya. Penundaan pelaksanaan pilkada yang dilakukan karena kondisi pandemi harus ditentukan kapan pelaksanaannya demi kepastian hukum yang berkeadilan dan bermanfaat sehingga pemerintah menetapkan penyelenggaraanya pada tanggal 9 Desember 2020.

Penyelenggaraan pemilihan kepala daerah (Pilkada) serentak di 270 kabupaten/kota pada tahun 2020 dapat dilaksanakan. Sebab, bencana wabah pandemi non alam Covid-19 dapat diantisipasi dengan protokol kesehatan yang ketat, tersosialisasi, dan terimplementasi dengan baik dalam setiap tahapan pemilihan pada seluruh unsur penyelengara pilkada seperti Komisi Pemilihan Umum (KPU) Badan Pengawas Pemilihan Umum (BAWASLU) dan Dewan Kehormatan Penyelenggara Pemilu (DKPP).

Tantangan bagi Komisi Pemilihan Umum (KPU) Badan Pengawas Pemilihan Umum (BAWASLU) dan Dewan Kehormatan Penyelenggara Pemilu (DKPP) adalah menyelenggarakan pemilu ditengah pandemi Covid-19, yakni tentang bagaimana teknis pelaksanaan pemilihan dengan mengacu pada protokol kesehatan sehingga pilkada terselenggara sesuai jadwal dan seluruh pihak yang terlibat tetap sehat tidak ada yang tertular virus tersebut.

Artikel ini menggunakan metode penulisan hukum normatif (Marzuki, 2017), dengan menggunakan pendekatan perundang-undangan, doktrinal dan pendekatan konseptual.Pengumpulan bahan hukum melalui studi kepustakaan (Library Research) dengan cara mengumpulkan bahan hukum primer, bahan hukum sekunder dan bahan hukum tersier. Bahan hukum primer adalah bahan hukum yang bersifat autoritatif artinya mempunyai otoritas. Bahan hukum primer berupa peraturan perundang-undangan, manuskrip resmi dan putusan putusan hakim, sedangkan bahan hukum sekunder adalah semua publikasi tentang hukum diluar perundang-undangan (Marzuki, 2017a). Bahan hukum primer berupa peraturan perundang-undangan yang terkait pada kajian ini berupa UndangUndang Dasar Negara Republik Indonesia Tahun 1945 Peraturan Pemerintah Pengganti Undang-Undang Nomor 2 tahun 2020 Peraturan Komisi Pemilihan Umum Nomor 5 Tahun 2020 Bahan hukum sekunder yakni literatur berupa bukubuku, jurnal, atau dokumen-dokumen yang berhubungan dengan 
permasalahan narkotika berdasarkan hukum pidana adat dayak Ngaju sedangkan bahan hukum tersier yakni kamus atau ensiklopedia untuk mengkaji gramatikal dari permasalahan ini (Susanti \& others, 2015). Teknik analisis bahan hukum menggunakan deskriptif analistik yakni menghubungkan antara premis mayor dan premis minor serta memberikan penjelasan secara detail terkait isu yang diangkat sehingga dapat ditarik kesimpulan.

Kajian ini bertujuan memberikan penjelasan terkait perspektif hukum tata negara terhadap pelaksanaan pemilihan kepala daerah serentak di tengah wabah bencana nonalam Pandemi Corona Virus Disease (Covid-19). Penulisan ini memberikan penjelasan terkait perspektif hukum tata negara terhadap pelaksanaan pemilihan kepala daerah serentak di tengah wabah bencana nonalam Pandemi Corona Virus Disease (Covid-19). Berdasarkan hal tersebut diatas, penulis tertarik mengkaji mengenai Aspek Hukum Tata Negara Dalam Pemilihan Kepala Daerah Serentak Disaat Pandemi Corona Virus Disease 2019 (COVID-19).

\section{PEMBAHASAN}

\section{Pemilihan Kepala Daerah Langsung}

Menurut Pasal 1 angka 2 UndangUndang Nomor 23 Tahun 2014 (UU Nomor 23 Tahun 2014) Tentang Pemerintahan Daerah, Pemerintahan Daerah adalah penyelenggaraan urusan pemerintahan oleh pemerintah daerah dan dewan perwakilan rakyat daerah menurut asas otonomi dan tugas pembantuan dengan prinsip otonomi seluas-luasnya dalam sistem dan prinsip Negara Kesatuan Republik Indonesia sebagaimana dimaksud dalam Undang-Undang Dasar Negara Republik Indonesia Tahun 1945. Pemerintahan daerah merupakan unsur pemerintahan yang ada di daerah dalam melaksanakan terdiri dari pemerintahan provinsi, pemerintahan kabupaten dan pemerintahan kota. Provinsi dipimpin gubernur, kabupaten dipimpin bupati dan kota dipimpin walikota yang dipilih secara langsung secara periodik 5 tahun sekali melalui pemilihan kepala daerah. Provinsi selain berstatus sebagai daerah juga merupakan wilayah administratif yang menjadi wilayah kerja bagi gubernur sebagai wakil Pemerintah Pusat dan wilayah kerja bagi gubernur dalam menyelenggarakan urusan pemerintahan umum di wilayah Daerah provinsi (Pasal 4 ayat 1 UU 23/2014). Daerah kabupaten/kota selain berstatus sebagai 
daerah juga merupakan wilayah administratif yang menjadi wilayah kerja bagi bupati/wali kota dalam menyelenggarakan urusan pemerintahan umum di wilayah Daerah kabupaten/kota (Pasal 4 ayat 2 UU 23/2014) (Kristian, 2017).

Pemilihan Umum (Pemilu) serentak merupakan sebuah amanah yang harus dilaksanakan oleh penyelenggara negara dalam hal ini adalah Komisi Pemilihan Umum (KPU) dan diawasi oleh Badan Pengawas Pemilu (Bawaslu). KPU dan Bawaslu memikili peran sentral dalam suksesnya sebuah pemilu serentak yang dilaksanakan dalam waktu yang tidak lama lagi. Kedua lembaga tersebut juga memiliki peran penting agar hak warga negara dapat terlindungi sehingga bisa mengambil peran dan hak dalam rangka ikut andil menyalurkan hak pilihnya tanpa diskriminasi atau tekanan dari pihak lain. sebagai contoh KPU harus memetakan Daftar Pemilih Tetap (DPT) secara benar, sedangkan Bawaslu berperan mengawasi jalannya pemilu serentak agar bejalan dengan tertib dan aman tanpa kecurangan dari pihak manapun.

Pemilihan Kepala Daerah langsung sebagaimana yang sekarang diterapkan di Indonesia merupakan koreksi atas pilkada terdahulu yang menggunakan sistem perwakilan oleh Dewan Perwakilan
Rakyat Daerah (DPRD). Model pemilihan langsung yang dilaksanakan di Indonesia sejak tahun 2005 menunjukkan perkembangan demokrasi yang semakin matang di tingkat daerah. Pilkada langsung dinilai sebagai perwujudan pengembalian hak-hak dasar masyarakat yang ada di daerah yaitu dengan memberikan kewenangan penuh dalam rangka memilih pimpinan daerah dan diharapkan mendorong dinamika dalam kehidupan demokrasi di tingkat lokal. Keberhasilan pilkada langsung seyogyanya mampu melahirkan pemimpin daerah yang demokratis yang sesuai kehendak dan tuntutan rakyat. Pilkada langsung dianggap sebuah langkah yang maju dan rasional.

Pada perkembangan selanjutnya disamping dilaksanakan secara langsung, pilkada saat ini juga diselenggarakan secara serentak (pilkada langsung dan serentak). Pilkada serentak pada periode pertama dilaksanakan pada tanggal 9 Desember tahun 2015 untuk pemilihan 269 kepala dan wakil kepala daerah yang meliputi 9 pemilihan gubernur dan wakil gubernur, 224 pemilihan bupati dan wakil bupati, serta 36 pemilihan walikota dan wakil walikota. Sesuai dengan UndangUndang Nomor 8 Tahun 2015, Pilkada serentak dilakukan bertahap. Yakni tahap pertama pada 9 Desember 2015, tahap kedua Februari 2017, tahap ketiga pada 
Juni 2018, tahap keempat tahun 2020, tahap kelima tahun 2022, dan tahap kelima tahun 2023.

Menurut penulis penyelenggaraan pilkada secara serentak setidaknya sedikit mengurangi dominasi partai politik (parpol) besar dalam melaksanakan kampanye di daerah. Jika pada pilkada langsung namun belum serentak para tokoh parpol sering turun ke daerah untuk melakukan kampanye secara keroyokan di daerah untuk mendukung kandidat dari partainya, maka dengan pilkada serentak mereka harus berhitung logistik dan tentu saja harus lebih arif mempertimbangkan mitra koalisinya agar terlihat komitmen berkoalisi sehingga tidak akan menurunkan elektabilitas kandidat yang didukungnya. Oleh karenanya, pilihan kendaraan parpol setiap kandidat kepala daerah berubah dari sebelumnya dimana selalu mempertimbangkan nama besar parpol karena dengan pilkada serentak mesin politik parpol besar sekalipun tidak akan maksimal diarahkan ke satu titik melainkan harus melayani sejumlah titik lainnya secara bersamaan.

Aspek Hukum Tata Negara pada Pemilihan Kepala Daerah Serentak disaat Pandemi Covid- 19

Tahapan Pemilihan Kepala Daerah tahun 2020 yang pada awalnya ditunda akibat pandemi Covid-19, berdasarkan peraturan KPU dilaksanakan pada bulan Desember 2020. Pasal 8b Peraturan Komisi Pemilihan Umum (PKPU) Nomor 5 Tahun 2020, menyatakan secara eksplisit bahwa, "Pelaksanaan pemungutan suara serentak yang ditunda karena terjadi bencana nonalam Corona Virus Disease 2019 (Covid-19), dilaksanakan pada tanggal 9 Desember 2020". PKPU ini merupakan penjabaran atas perintah Pasal 201A ayat (2) Peraturan Pemerintah Pengganti Undang-Undang (Perppu) Nomor 2 Tahun 2020 yang sudah disetujui menjadi undang-undang, yang memyebutkan bahwa, "Pemungutan suara serentak yang ditunda sebagaimana dimaksud pada ayat (1) dilaksanakan pada bulan Desember 2020". Tulisan ini akan lebih banyak mengupas aspek hukum tata negara bserta implikasi dari pelaksanaan Pilkada tersebut, khususnya menyangkut hak-hak dasar warga negara yang berpotensi diabaikan saat Pilkada digelar dimasa pandemi Covid-19.

Apalagi ada prediksi yang mengatakan bahwa pandemi ini baru selesai paling cepat di bulan September 2020 dan paling lama bulan Januari 2021. Sehingga, bisa saja aktivitas KPU, khususnya perekrutan tenaga ad hoc dan tahapan pemilihan baru bisa dijalankan di tahun 2021. Jika dicermati, keputusan 
penundaan Pilkada adalah keputusan terbaik agar konsetrasi negara tidak terbagi. Di situasi seperti saat ini, negara harus fokus pada penanganan Covid-19 yang konfirmasi positifnya sudah mencapai angka ribuan. Jika konsentrasi terbagi, bisa saja kinerja KPU dan Pemerintah banyak yang terabaikan dan hasil kinerja yang dilakukan pemerintah bisa saja tidak menuai hasil maksimal (Alim, 2020).

Berdasarkan data dari International IDEA (Institute for democracy and electoral assistance), selama kurun waktu 21 Februari 2020 hingga 19 Juli 2020, setidaknya terdapat 67 negara dan teritori di seluruh dunia yang telah memutuskan menunda pemilu nasional dan subnasional karena pandemi Covid-19, dari jumlah ini, setidaknya 23 negara telah memutuskan menunda pemilu dan referendum nasional. Namun diperiode yang sama, terdapat 49 negara dan teritori yang telah memutuskan untuk menyelenggarakan pemilu nasional atau subnasional sebagaimana direncanakan semula, meskipun ada kekhawatiran terkait pandemi Covid-19 Dari jumlah ini, setidaknya 31 negara telah menyelenggarakan pemilu atau referendum nasional (Idea.Int, 2020).

Tantangan utama dalam gelaran pilkada serentak ditengah pandemi yang terberat adalah respon pemilih dalam pilkada tersebut. Resiko dan bahaya terpapar virus Covid-19, adalah pertimbangan pokok yang menjadi alasan pemilih untuk terlibat langsung dalam menyalurkan hak pilihnya, hal ini harus segera direspon oleh Pemerintah. Negara melalui Pemerintah, harus memberikan jaminan rasa aman bagi warganya, agar hak pilih dapat disalurkan seaman dan senyaman mungkin. Hal ini dikuatirkan bisa menimbulkan dampak yang harus ditanggung oleh pemerintah yakni minimnya partisipasi pemilih dalam pemilu tersebut. Berdasarkan data yang diolah dari Internasional IDEA, tingkat partisipasi pemilih dinegara-negara yang menggelar pemilu dimasa pandemi Covid19, rata-rata mengalami penurunan dibandingkan pemilu sebelumnya (Idea.Int, 2020a)

Sebagai parameter keberhasilan pelaksanaan pemilu di masa pandemi Covid-19 yakni di Negara Polandia dan Korea Selatan, ada beberapa simpulan kecil dibalik kesuksesan pelaksanaan pemilu pada kedua negara tersebut, namun yang perlu digarisbawahi bahwa pelaksanaan pilkada serentak di masa pandemi Covid-19 tidak mudah untuk diimplementasikan di Indonesia: Pertama, jumlah partisipan atau pemilih. Berdasarkan data pada Juni 2020 jumlah Data Penduduk Potensial Pemilih Pemilu 
(DP4) yang diserahkan Kementerian Dalam Negeri (Kemendagri) kepada KPU sebanyak 105,852 juta pemilih. Jumlah ini besar dan lebih banyak tiga kali lipat dari pemilih yang terdaftar dalam Pemilu Presiden Polandia atau dua kali lipat dari jumlah pemilih saat Pemilu majelis nasional Korea Selatan. Perlu diketahui bahwa pemilih yang terdaftar di Korea Selatan yang hanya berjumlah 43.994.247 sementara di Polandia sebanyak 30,268,543. Apabila berkehendak pilkada nanti berlangsung lancar setidaknya semua pihak harus bekerja lebih keras disbanding negara Polandia atau Korea Selatan (Liputan6, 2020).

Kedua, tingkat kepercayaan publik (public trust) kepada pemerintah berserta seluruh perangkat yang terlibat dengan pelaksanaan pilkada dimasa pandemi Covid-19. Mulai dari penyelenggara pemilihan hingga ke tenaga medis termasuk mengenai kemampuan pemerintah dalam penanganan pandemi Covid-19. Perlu dicermati jumlah kasus Covid-19 di Korea Selatan per tanggal 8 April 2020 atau seminggu sebelum pelaksanaan Pemilu legislatif untuk memilih majelis nasional pada tanggal 15 April 2020, hanya mencapai 10.384 kasus. Bahkan penambahan kasus baru setiap hari terus berkurang, dimana pada tanggal tersebut, terhitung hanya terdapat 53 kasus baru perhari. Demikian pula dengan Polandia. Pada tanggal 5 Juli atau seminggu jelang Pemilu Presiden Polandia, total jumlah kasus hanya mencapai 35.950 kasus, dengan jumlah kasus baru per hari sebanyak 231 kasus. Sementara itu di Indonesia per tanggal 9 Agustus 2020 telah mencapai 125,396 kasus, dengan jumlah kematian sebanyak 5.723 kasus dan yang berhasil disembuhkan sebanyak 80.952. Grafik penambahan kasus perhari terus meroket, dimana per tanggal 8 Agustus 2020 terhitung terdapat 2.277 kasus baru. Karena itu kepercayaan dan rasa aman bagi warga negara untuk memilih saat pilkada akan berbanding lurus dengan upaya pemerintah dalam menekan jumlah kasus pandemi Covid-19 (Worldometers, 2020).

Ketiga, budaya disiplin masyarakat yang perlu dibenahi. Korea Selatan maupun Polandia merupakan negara yang cukup disiplin dalam menjalankan protokol kesehatan. Sehingga membantu pelaksanaan pemilu disaat bersamaan juga menghadapi pandemi Covid-19. Oleh karena itu dengan jumlah partisipan di Indonesia yang mencapai 105,852 juta pemilih, maka salah satu kunci sukses pilkada serentak, sangat ditentukan oleh seberapa disiplin masyarakat dalam menjalankan protokol kesehatan. Jika 
tidak, maka pilkada hanya akan menjadi tempat munculnya klaster baru covid-19. Karena itu, peran Pemerintah demikian penting dalam upaya membangun kedisiplinan masyarakat. Keempat, regulasi yang digunakan sebagai landasan hukum dalam bentuk larangan dan sanksi terhadap pelanggaran protokol kesehatan pada saat menjelang dan saat pelaksanaan pilkada. Pada Negara Korea Selatan, regulasi pemilu sudah didesain agar mengakomodir pemilu dalam kondisi darurat. Sementara Indonesia belum memiliki pengalaman yang cukup menggelar proses electoral dalam kondisi darurat, seperti dimasa pandemi Covid-19 ini. Bahkan Perppu Nomor 2 Tahun 2020, yang menjadi dasar penundaan pilkada serentak, tidak memberikan norma yang memadai untuk melaksanakan pilkada di tengah bencana nonalam.

Kelima, ketersediaan infrastruktur baik itu infrastruktur pilkada termasuk infrastruktur kesehatan. Karena itu harus dipastikan kelayakannya termasuk dalam hal optimalisasi daya dukung teknologi agar pilkada dapat dijalankan secara efektif dan efisien, sekaligus mampu memberikan rasa aman bagi pemilih. Pemanfaatan teknologi ini akan membantu manajemen pilkada dengan lebih baik. Sebagai contoh pada Korea Selatan daftar pemilih bahkan hanya disusun dalam rentan waktu 5 hari. Bandingkan dengan Indonesia 90 persen tahapan bisa dihabiskan hanya untuk menyiapkan Daftar Pemilih Tetap (DPT), termasuk DPT Hasil Perbaikan (DPTHP) hingga Daftar Pemilih Tambahan (DPTb). Keenam, untuk melaksanakan pilkada langsung dan serentak di tengah pandemi Covid-19, yang dikualifikasikan sebagai kondisi darurat, maka anggaran setidaknya dikalkulasikan minimal dua kali lipat dari sebelumnya.

Penulis menilai bahwa potensi kecurangan dan pelanggaran dalam pilkada dimasa pandemi Covid-19 adalah sebagai berikut : Pertama, saat ini kondisi ekonomi yang menurun akibat pandemi Covid-19 bisa memicu tumbuhnya pragmatisme politik uang. Para pemodal atau calon yang kuat akan memanfaatkan situasi ini untuk memenangkan kompetisi secara tidak sehat. Secara akal demokrasi itu mahal dan butuh modal, sulit menerapkan dan menghasilkan demokrasi yang jujur, adil, dan bermartabat apabila kesenjangan ekonomi masyarakat belum terselesaikan, atau setidak-tidaknya dapat diminimalisir terlebih dahulu. Negara harus mampu menjamin hak politik dan hak ekonomi secara selaras dan berkesinambungan.

Kedua, pelaksanaan pilkada serentak dimasa pandemi Covid-19 bisa jadi menimbulkan ancaman terhadap hak 
untuk hidup bagi warga negara, yang telah dijamin oleh konstitusi. Pasal 28A UUD 1945 secara eksplisit menyebutkan bahwa, "Setiap orang berhak untuk hidup serta berhak mempertahankan hidup dan kehidupannya". Ketentuan tersebut dipertegas dalam Pasal 28H ayat (1) UUD 1945, yang menyatakan bahwa, "Setiap orang berhak hidup sejahtera lahir dan batin, bertempat tinggal, dan medapatkan lingkungan hidup baik dan sehat serta berhak memperoleh pelayanan kesehatan”. Ini belum termasuk pengaturan operasional atas hak untuk hidup serta perlindungan kesehatan, sebagaimana diatur dalam Undang-Undang Nomor 39 Tahun 1999 Tentang Hak Asasi Manusia dan Undang-Undang Nomor 36 Tahun 2009 Tentang Kesehatan. Karena itu pelaksanaan pilkada di tengah pandemi Covid-19 tidak boleh sampai mengancam keselamatan jiwa warga negara.

Sebagaimana dikemukakan oleh

Jimly Asshiddiqie, perlindungan dan penghormatan terhadap hak asasi manusia atau hak warga negara itu merupakan pilar yang sangat penting dalam setiap negara yang disebut negara hukum. (Jimly Asshiddiqie, 2006) Dipertegas lagi jika dalam suatu negara hak asasi manusia terabaikan atau dilanggar dengan sengaja dan penderitaan yang ditimbulkannya tidak dapat diatasi secara adil, maka negara yang bersangkutan tidak dapat disebut negara hukum dalam arti yang sesungguhnya (Asshiddiqie, 2019).

Menurut Rhona K. Smith, dkk dalam Apeles Lexi Lonto, dkk, terdapat 1 (satu) prinsip pokok Hak Asasi Manusia (HAM) yaitu prinsip kesetaraan yang mengandung pengertian meletakkan semua orang terlahir bebas dan memiliki kesetaraan dalam HAM. Kesetaraan mensyaratkan adanya perlakukan yang setara, yaitu pada situasi yang sama harus diperlakukan dengan sama dan dengan perdebatan dalam situasi yang berbeda harus dilakukan secara berbeda pula. Masalah muncul ketika seseorang berasal dari posisi yang berbeda dan diperlakukan secara sama. Jika perlakuan yang sama ini terus diberikan, tentu saja perbedaan ini akan terjadi terus menerus walaupun standar HAM telah meningkat. Karena itulah penting untuk mengambil langkah selanjutnya guna mencapai kesetaraan (Lonto et al., 2016).

Ketiga, selama pemerintah belum bisa memastikan adanya jaminan keselamatan bagi setiap warga negara dalam proses pelaksanaan pilkada serentak, sangat mungkin masyarakat akan memilih menahan diri untuk menyalurkan hak pilihnya daripada harus menanggung resiko terpapar Covid-19. Persoalan tersebut bisa jadi akan berbanding terbalik 
dengan angka partisipasi pemilih sebesar 77,5 persen yang ditargetkan oleh KPU. Berdasarkan pengalaman negara-negara lain mayoritas negara yang menggelar pilkada dimasa pandemi Covid-19, mengalami penurunan tingkat partisipasi pemilih. ketidakpastian rasa aman dan jaminan kesehatan yang membuat pemilih ragu atau apatis untuk menggunakan hak pilihnya, sebuah tantangan berat yang segera diatasi oleh pemerintah mengenai cara untuk mengendalikan pandemi Covid19.

Keempat, dalam kondisi seperti ini bisa saja pandemi Covid-19 akan menguntungkan petahana dan bisa juga merugikan kandidat lain dengan beberapa alasan: pertama, petahana memiliki kewenangan dan program yang berpotensi diarahkan untuk kepentingan pribadinya, untuk membangun citra politiknya, ataupun sebagai sarana untuk mengumpulkan pembiayaan politiknya. Kedua, petahana memiliki ruang komunikasi politik yang cukup dengan masyarakat, pada beberapa kasus justru banyak petahana yang melanggar protokol kesehatan dengan menciptakan kerumunan di kediamannya. Ketiga, elektabilitas petahana cenderung stabil, sementara pada sisi lain kandidat lainnya harus kerja keras membangun citra akibat situasi yang serba terbatas dimasa pandemi baik bentuk maupun ruang komunikasi kepada publik.

Kelima, dapat terjadi politisasi bantuan sosial (bansos) penanganan Covid-19, sebab pejabat di daerah khususnya petahana memiliki keseluruhan perangkat yang memungkinkan dirinya untuk menyalahgunakan kewenangan, program dan kegiatan lainnya untuk kepentingan pribadi, kelompok, atau golongan. Larangan bagi petahana untuk menggunakan kewenangan, program, ataupun kegiatan yang menguntungkan dirinya, secara tegas sudah diatur dalam Pasal 71 ayat (3) Undang-Undang Nomor 10 Tahun 2016 tentang Perubahan Kedua atas Undang-Undang Nomor 1 Tahun 2015 tentang Penetapan Peraturan Pemerintah Pengganti Undang-Undang Nomor 1 Tahun 2014 tentang Pemilihan Gubernur, Bupati, dan Walikota Menjadi Undang-Undang (UU 10 Tahun 2016 tentang Pilkada), yang menyatakan bahwa, "Gubenur atau Wakil Gubernur, Bupati atau Wakil Bupati, Walikota atau Wakil Walikota, dilarang menggunakan kewenangan, program, dan kegiatan yang menguntungkan atau merugikan salah satu pasangan calon baik di daerah sendiri maupun di daerah lain dalam waktu 6 (enam) bulan

Pemerintah Indonesia sebaiknya mulai menjalin komunikasi dan 
konsolidasi dengan pemerintah daerah, beserta instrumen penyelenggara Pilkada secara lebih intens. Selain itu, perlunya sosialisasi bagi warga masyarakat di seluruh daerah juga menjadi vital untuk diagendakan secara khusus, mengingat Pilkada di tahun 2020 ini juga berada dalam situasi darurat akibat bencana wabah Covid-19. Artinya opini publik yang saat ini berseteru, harus dijadikan dasar untuk menentukan langkah susulan ke depan. Selain itu, keputusan maupun kebijakan susulan yang dibuat harus lah menjembatani kepentingan orang banyak tanpa menitikberatkan pada kecenderungan terhadap salah satu kelompok masyarakat (Rizki \& Hilman, 2020).

Kegiatan kampanye yang dilakukan calon kepala daerah secara tegas diatur oleh KPU dengan menetapkan PKPU Nomor 13 tahun 2020 yang merevisi peraturan sebelumnya. Terdapat dalam Pasal 58 PKPU tersebut yang menyatakan para kandidat dalam pilkada serentak 2020 harus mengutamakan kegiatan kampanye di media sosial dan media daring. Jika kampanye tidak dapat dilakukan melalui media sosial dan media daring, maka dibolehkan pertemuan tatap muka dengan jumlah peserta yang hadir paling banyak 50 orang serta menerapkan protokol kesehatan untuk mencegah penyebaran Covid-19. Pada pasal 88C, KPU dengan tegas melarang tim kampanye melaksanakan kegiatan yang biasanya mengumpulkan massa dalam jumlah besar seperti rapat umum, kegiatan kebudayaan seperti pentas seni atau konser musik, kegiatan olahraga, perlombaan, kegiatan sosial, atau peringatan hari ulang tahun partai politik. Kampanye di media sosial mungkin bisa lebih menjangkau para pemilih. Masyarakat juga dapat dengan mudah menyampaikan aspirasi mereka lewat komentar pada unggahan para calon. Namun yang perlu diwaspadai dengan sebagian besar kampanye beralih ke ruang virtual, ancaman disinformasi dan berita bohong atau hoaks yang semakin luas bisa membuat masyarakat semakin terpolarisasi.

Menurut Moh. Mahfud MD, Demokrasi mutlak dibutuhkan karena Negara kebangsaan dibangun dari berbagai ikatan primordial yang dikuatkan secara integrasi kedalam satu bangsa yang terdiri dari agama, suku, ras, daerah, bahasa, ikatan primordial di Indonesia lebih dikenal dengan SARA (Suku Agama Ras Antargolongan). (Moh. Mahfud. MD, 2010) Pelaksanaan dari konsep negara hukum seharusnya diutamakan sebagai prioritas dalam sebuah pilkada yang sedianya dilaksanakan ditengah pandemi Covid-19. Sebagaimana pengertian negara 
hukum menurut para ahli adalah negara yang menolak melepaskan kekuasaan tanpa kendali. Negara yang penyelenggaraannya berdasar atas hukum yang adil dan demokratis (MD, 2009)

Penulis berpendapat bahwa isu SARA dalam konteks pilkada yang demokratis tidak boleh muncul ke permukaan, isu ini sangat berbahaya karena bisa menimbulkan dis-integrasi bangsa Indonesia. Prinsip Negara Kesatuan Republik Indonesia (NKRI) dan Bhineka Tunggal Ika wajib sepatutnya dijadikan pilar penting bagi keberlangsungan kehidupan berbangsa dan bernegara termasuk dalam konteks pilkada langsung dan serentak terlebih lagi pada saat dunia termasuk Indonesia sedang menghadapi wabah pandemi Covid-19. Sebagai negara hukum yang beradab dan berbudaya pancasila, hukum ditempatkan sebagai panglima tertinggi yang, Hukum tata negara mengharuskan putaran dan perubahan kepemimpinan didaerah atau pilkada serentak tetap harus terlaksana dengan situasi dan kondisi yang menyesuaikan keadaaan pandemi Covid19 yang terjadi saat ini.

\section{KESIMPULAN}

Hukum Tata Negara (HTN) merupakan dasar teori dari pelaksanaan penyelenggaraan negara yang mengatur hubungan antar lembaga negara baik secara horisontal maupun secara vertikal dari pusat hingga derah termasuk sistem politik demokrasi yang teraplikatif dalam sebuah pemilihan umum dan pemilihan kepala daerah. HTN mengatur periodesasi pemilihan pemimpin secara berkala dan periodik. Pemilihan pemimpin daerah hingga nasional dilakukan setiap 5 (lima) tahun sekali. Pemimpin daerah yang dimaksud yaitu yakni gubernur dan wakil gubernur, bupati dan wakil bupati, serta walikota dan wakil walikota. Pergantian pemimpin daerah sebagaimana dimaksud dilakukan melalui sebuah pemilihan umum kepala daerah yang dilakukan secara serentak dan demokratis. Meskipun saat ini bangsa Indonesia sedang bertarung melawan wabah Covid-19 namun dengan protokol kesehatan dan aturan pelaksanaan pilkada yang terencana dan aman bagi warga masyarakat, maka diharapkan akan terpilih kepala daerah secara demokratis dan dihrapkan mampu membawa dan memimpin daerahnya menjadi lebih maju dan baik lagi.

\section{DAFTAR RUJUKAN}

Ahmad, S. (2012). Hukum tata negara \& hukum administrasi negara: dalam perspektif fikih siyasah. Sinar Grafika.

Alim, N. (2020). Dampak Penundaan Pilkada Serentak 2020 Di Tengah 
Pandemi Covid-19. Antara Megapolitan.

https://megapolitan.antaranews.com/b erita/93100/dampak-penundaanpilkada-serentak-2020-di-tengahpandemi-covid-19

Asshiddiqie, J. (2019). Konstitusi dan konstitusionalisme Indonesia. Sinar Grafika.

Idea.Int. (2020). Global overview of COVID-19: Impact on elections. Idea.Int. https://www.idea.int/newsmedia/multimedia-reports/globaloverview-covid-19-impact-elections

Kristian, K. (2017). Dinamika Pemekaran Daerah di Indonesia Menurut Undang-Undang Nomor 23 Tahun 2014 Tentang Pemerintahan Daerah. Jurnal Ilmu Hukum Universitas Palangka Raya, 12(2), 15-25.

Liputan6. (2020). KPU Terima 456.256 Tambahan Pemilih Pemula DP4 untuk Pilkada 2020. Liputan6.Com. https://www.liputan6.com/pilkada/rea d/4283282/kpu-terima-456256tambahan-pemilih-pemula-dp4untuk-pilkada-2020

Lonto, A. L., Lolong, W., \& Pangalila, T. (2016). Buku: Hukum Hak Asasi Manusia. Ombak.

Marzuki, M. (2017). Penelitian Hukum: Edisi Revisi. Prenada Media.

MD, M. M. (2009). Konstitusi dan Hukum dalam Kontroversi isu. Rajawali Pers.

Rizki, S. C., \& Hilman, Y. A. (2020). Menakar Perbedaan Opini Dalam Agenda Pelaksanaan Kontestasi Pilkada Serentak Di Tengah Covid19. Jurnal Ilmiah Muqoddimah: Jurnal Ilmu Sosial, Politik Dan
Hummanioramaniora, 4(2), 143-155.

Susanti, D. O., \& others. (2015). Penelitian Hukum.

Worldometers. (2020). South Korea Coronavirus Cases.

Worldometers.Info. https://www.worldometers.info/coron avirus/country/south-korea/

\section{Peraturan Perundang-Undangan}

Undang-Undang Dasar Negara Republik Indonesia Tahun 1945

Peraturan Pemerintah Pengganti UndangUndang Nomor 2 tahun 2020

Undang-Undang Nomor 23 Tahun 2014 Tentang Pemerintahan Daerah

Peraturan Komisi Pemilihan Umum Nomor 5 Tahun 2020 